\title{
A baseline limnological study of Wagendrift Dam (Thukela basin, KwaZulu-Natal)
}

\author{
Rob C Hart \\ School of Botany and Zoology, University of Natal, P/Bag X01, Scottsville, 3209, Pietermaritzburg, South Africa
}

\begin{abstract}
Basic features of the physical and biological limnology of Wagendrift Dam, a moderately large impoundment on the Boesmans River, were studied between July 1989 and May 1990. This man-made lake showed a typical monomictic pattern of summer stratification (November through April) and holomictic winter circulation (May to October). Water quality was chemically good (Department of Water Affairs and Forestry records), with little evidence of nutrient enrichment. Water clarity during the study was moderately low (mean SD and $K_{\mathrm{dPAR}}$ values of $0.45 \mathrm{~m}$ and $2.55 \mathrm{~m}^{-1}$ ), with little evidence of persistent mineral turbidity, suggesting reasonably satisfactory catchment conditions. In keeping with the low nutrient status, surface chlorophyll content remained below $5 \mu \mathrm{g} \ell^{-1}$ throughout the study. In terms of ecological groupings, the phytoplankton was numerically dominated mostly by 'Competitive' green algae for most of the year. 'Stress-tolerant' cyanophytes were continuously sparse, but were marginally more abundant during summer stratification. Diatoms and other disturbance-tolerant 'ruderal' algae persisted throughout the year. No spring peak in ruderal algae was evident, but it may have been masked by high zooplankton grazing pressure. An autumnal peak in ruderal algae coincided broadly with flood-related inflows and annual de-stratification.

Zooplankton was dominated (numerically and/or gravimetrically) by typical clear-water taxa. The copepod Tropodiaptomus spectabilis and cladoceran Daphnia pulex along with various unidentified cyclopoids and rotifers were seasonally persistent, while other cladoceran taxa (D. laevis and Diaphanosoma excisum) showed considerable seasonal periodicity. Zooplankton standing stock was collectively substantial, annually averaging around $0.65 \mathrm{~g} \cdot \mathrm{m}^{-2} \mathrm{DM}$, and approaching $1 \mathrm{~g} \cdot \mathrm{m}^{-2} \mathrm{DM}$ in spring/early summer, implying potentially significant natural grazer-control of phytoplankton, aided perhaps by large numbers of benthic bivalve molluscs (Unio caffer), observed stranded in littoral margins following reservoir draw-down.
\end{abstract}

\section{Nomenclature}

CSIR Council for Scientific and Industrial Research

DM Dry mass

DWA Department of Water Affairs

DWAF Department of Water Affairs and Forestry

$\mathrm{K}_{\mathrm{d}} \quad$ Down welling extinction coefficient

MAR Mean annual runoff

PAR Photosynthetically active radiation (400 to $700 \mathrm{~nm}$ )

SD Secchi depth transparency

\section{Introduction}

The level of limnological knowledge and understanding of South African man-made lakes belies both their dominance of the country's limnetic landscape (Allanson et al.,1990), and their strategic importance in this generally water-scarce region (Noble and Hemens,1978). Studies undertaken within the Inland Water Ecosystems thrust of the CSIR's former National Programmes for Environmental Sciences (Allanson and Jackson, 1983; Breen, 1983; National Institute for Water Research, 1985) provided holistic (i.e. physical, chemical and biological) understanding of limnological structure and functioning of three of the country's major reservoirs with strikingly different features (high mineral turbidity, clear oligotrophic waters, and hypertrophic waters, respectively), with a sister study of a smaller turbid system (Pieterse and Keulder, 1982). The general limnology of most of the remainder of more than 500 major state dams (Department of Water Affairs,

面(033) 260-5104; fax: (033) 260-5105; e-mail: Hartr@nu.ac.za Received 19 December 2000; accepted in revised form 11 July 2001.
1986; Uys, 1996) is largely undescribed, apart from Walmsley and Butty's (1980) baseline survey of 21 impoundments and various other narrower studies addressing general physico-chemical limnology (e.g. Tow, 1981; Dörgeloh et al., 1993), particular biotic components (e.g. Van Ginkel, 1987) and problems (e.g. Selkirk and Hart, 1984), or specific catchment issues wider than the impoundments themselves (e.g. O'Keeffe et al., 1996; Keinzle et al., 1997; Graham et al., 1998). Baseline limnological information resulting from often time-constrained studies obviously cannot encompass the hydrological variability of the region (Schulze, 1997), and provides no information on progressive and longer-term changes (like eutrophication, salinisation, and sedimentation) that generally accompany or are associated with catchment developments.

The present study was undertaken to provide some baseline knowledge of the general limnology of Wagendrift Dam, one such previously unstudied impoundment on the Boesmans River at Estcourt, in the midlands of KwaZulu-Natal. Findings of a parallel sister study of Spioenkop Dam, a highly turbid reservoir on the upper Thukela River, are published elsewhere (Hart, 1999).

The primary objective of the present study was to determine the seasonal characteristics of phytoplankton and zooplankton abundance and composition in Wagendrift Dam in relation to the general thermal and hydrological characteristics of this superficially clear-water reservoir. Given corresponding information on Spioenkop Dam, a reasonably proximate but highly turbid system (Hart, 1999) lying in a somewhat drier watershed, but with otherwise similar catchment geology, soil type, erodibility index, and vegetation (Midgley et al., 1994; Schulze, 1997), some comparative evaluation of drainage basin conditions on limnological characteristics was expected (Hynes, 1975). 


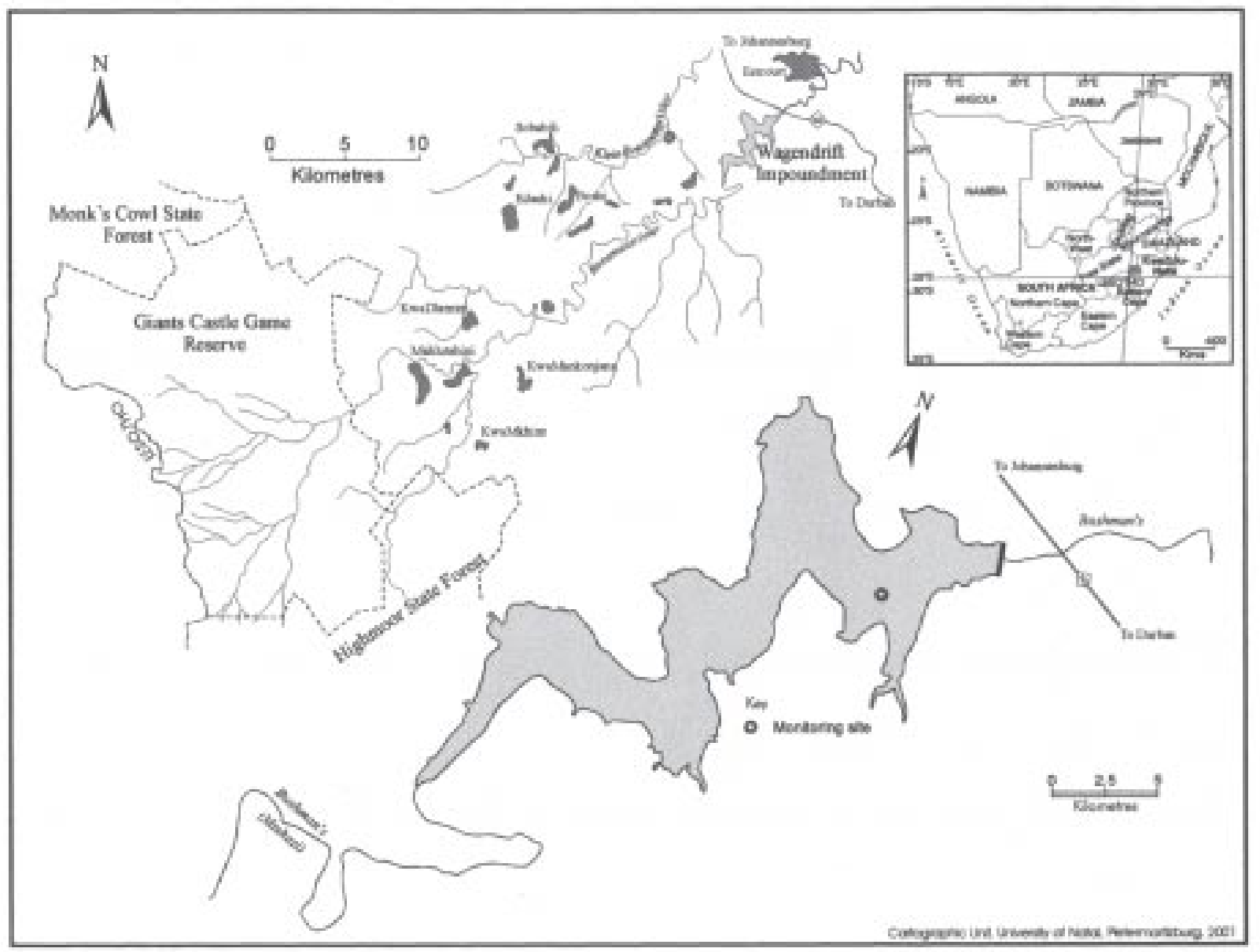

Figure 1

Geographical location of Wagendrift Dam (right inset), its catchment features (upper), and general morphometry of the impoundment, showing sampling site locality (lower)

\section{TABLE 1}

Morphometric features of Wagendrift Dam at full supply level. Data from Noble and Hemens (1978), DWA (1986) and Midgley et al. (1994).

\begin{tabular}{|l|c|}
\hline \multicolumn{2}{|c|}{ Catchment attributes } \\
\hline Catchment area $\left(\mathrm{km}^{2}\right)$ & 744 \\
MAR from catchment $\left(10^{6} \mathrm{~m}^{3}\right)$ & 233 \\
\hline \multicolumn{2}{|c|}{ Reservoir attributes } \\
\hline Surface Area (ha) & 508 \\
Maximum depth (m) & 30.5 \\
Mean depth (m) & 11.8 \\
Volume (10 $\left.\mathrm{m}^{3}\right)$ & 58.4 \\
Elevation above sea level (m) & 1179 \\
Mean hydrological retention time (d) & 91 \\
\hline
\end{tabular}

\section{Study site}

Wagendrift Dam is a moderate-sized reservoir near Estcourt in the KwaZulu-Natal midlands, created in 1971 by impoundment of the Boesmans (Bushman's) River (at 29 $02^{\prime} \mathrm{S}, 29^{\circ} 51^{\prime} \mathrm{E}$ ) - primarily to provide water for this small farming and light industrial town. The headwaters of the Boesmans River (or Boesmansrivier), a sizeable right-bank tributary of the Thukela River, rise in conserved game reserve and state forest areas in the Drakensberg mountains. The river then flows past extensively populated rural areas to the concrete wall of Wagendrift Dam, some $65 \mathrm{~km}$ downstream from the river's headwater sources (Fig. 1). Relevant morphometric and related attributes of the impoundment are summarised in Table 1.

\section{Methods}

Wagendrift Dam was sampled at approximately monthly intervals between July 1989 and May 1990. Routine monitoring was undertaken in the early afternoon, at a deep-water station near the dam wall (see Fig. 1).

Vertical profiles of temperature and underwater light intensity were measured using appropriate electronic meters (YSI thermistor thermometer, Lambda PAR radiometer). Water column stability was estimated as the squared Brunt-Väsäilä buoyancy frequency term $\left(\mathrm{N}^{2} \cdot \mathrm{s}^{-2}\right)$, calculated as:

$$
\mathrm{N}^{2}=\left(\frac{-\mathrm{g}}{\rho_{0}}\right)\left(\frac{\partial \rho}{\partial_{2}}\right)
$$

where: $\begin{aligned} \mathrm{g}= & 9.81 \mathrm{~m} \cdot \mathrm{s}^{-1} \\ \frac{\partial \rho}{\partial_{2}}= & \text { density gradient of the water column of mean density } \\ & \rho_{\mathrm{o}} \text { (Paterson et al.,1984). }\end{aligned}$ 
To avoid localised surface heating effects, the surface $1 \mathrm{~m}$ was disregarded in respective calculations of water column stability and temperature.

Down-welling attenuation of photosynthetically active radiation $\left(K_{\mathrm{dPAR}}, \mathrm{m}^{-1}\right)$ was estimated as:

$$
K \mathrm{~d}=\frac{\ln I_{0}-\ln I_{\mathrm{z}}}{\mathrm{z}}
$$

where:

$I_{0}=$ light intensity at depth $0 \mathrm{~m}$

$I_{\mathrm{z}}=$ light intensity at depth $\mathrm{z} \mathrm{m}$

$\mathrm{z}=$ depth interval between measured values.

Water transparency was determined with a white Secchi disc (200 mm diameter).

Chlorophyll concentration and algal composition and abundance were determined from integrated hose-pipe samples of water encompassing the upper $2 \mathrm{~m}$ of the water column. Samples for chlorophyll were filtered on site (Whatmans GF/F filters). Filters were briefly air-dried and stored in the dark during transportation to the laboratory, where boiling $95 \%$ methanol extraction was undertaken within $6 \mathrm{~h}$ of sample collection. Chlorophyll concentration $\left(\mu \mathrm{g} \cdot \ell^{-1}\right)$ was determined, disregarding degradation products, from spectrophotometric absorbances (E) of centrifuged extract read at 665 and $750 \mu \mathrm{m}$, using the conventional formulation:

$$
\text { Chlorophyll } a=\frac{13.9 \times 0.89 \times\left(\mathrm{E}_{665}-\mathrm{E}_{750}\right) \times \mathrm{v}}{(\mathrm{V} \times 1)}
$$

where:

$$
\begin{aligned}
& \mathrm{v}=\text { volume of solvent }(\mathrm{m} \ell) \\
& \mathrm{V}=\text { volume of sample filtered }(\ell) \text { and } \\
& \mathrm{l}=\text { photometric light-path length }(\mathrm{cm}) .
\end{aligned}
$$

Samples for determination of phytoplankton abundance and composition were preserved in the field with Lugol's iodine, and subsequently analysed using conventional (Ütermohl) inverted microscopy (Lund et al., 1958). Samples of around $5 \mathrm{~m} \ell$ were sedimented, and consecutive transects of the counting chamber were enumerated until a total count of at least 200 'units' was obtained. 'Units' comprised individual cells, filaments and other colony types as applicable in different taxa, without differentiating between large and small colonies. Taxa were routinely identified to generic level, and further distinguished to (unnamed) species level as far as possible for enumeration. Individual taxa were also categorised according to Grime's (1979) three life-style characteristics $(\mathrm{C}, \mathrm{S}, \mathrm{R})$ as elaborated for planktonic algae on the basis of morphological features (Reynolds, 1984) as exploitative competitive colonists (C), acquisitive stress tolerators (S) and attuning disturbance-tolerant ruderals (R) (Reynolds, 1996). This non-taxonomic classification is particularly useful for ecological interpretations of phytoplankton dynamics, especially in view of its heuristic value in considering ecosystem sustainability (Reynolds, 2000).

Zooplankton was collected in bottom to surface vertical hauls with a conical tow-net (mouth diameter $=25 \mathrm{~cm}$, reducing cone $=$ $50 \mathrm{~cm}$, mesh aperture $=53 \mu \mathrm{m})$. Samples were briefly $(\leq 30 \mathrm{~s})$ fixed by flooding with $95 \%$ ethanol, and then preserved with formalin (final concentration of $\pm 5 \%$ ) for subsequent laboratory analysis of the entire sample (for cladocerans, adult calanoid copepods, Chaoborus) or subsamples of variable fractions (1/5 to 1/50), for cyclopoids and juvenile calanoid copepods, and rotifers. Resulting abundance values (individuals $\cdot \mathrm{m}^{-2}$ ) were estimated assuming 100\% net sampling efficiency. Corresponding approximate estimates of biomass were made from the numerical counts using the published or estimated dry mass values for individual species and/or lifehistory stages specified in Table 4.

Mean clutch sizes (eggs.individual ${ }^{-1}$ ) and corresponding body lengths $(\mathrm{mm})$ were determined microscopically for 25 egg-bearing individuals (or all present in the sample) on each sampling date, using conventional measures (see Hart, 1996).

\section{Results}

\section{Thermal characteristics}

A typical pattern of monomictic holomixis was evident in Wagendrift Dam (Fig. 2). Water column temperatures increased significantly from winter isothermal values of below $11^{\circ} \mathrm{C}$ towards the end of July to above $13^{\circ} \mathrm{C}$ by mid-September. Vertical penetration of surface-heated waters, as reflected in the plunging of all isotherms lower than $19^{\circ} \mathrm{C}$, was sustained until mid-December, when moderately strong thermal stratification developed with maximum vertical differences of between 4 and $5^{\circ} \mathrm{C}$ below $1 \mathrm{~m}$ (Fig. 2); corresponding $\mathrm{N}^{2}$ stability values reached around $0.006 \mathrm{~s}^{-2}$ (Fig. 3). During the stratified period, near-surface temperatures were maintained at $23^{\circ} \mathrm{C}$ and above, with episodes of strong localised surface heating evident in the mid-December and early March profiles. Isothermy was apparent in early May, indicating that turnover had occurred during April. Subsequent cooling was presumably very rapid, requiring the entire water column to cool by some $7^{\circ} \mathrm{C}$ in little over a month to reach winter lows comparable to those recorded at the onset of the study (below $11^{\circ} \mathrm{C}$ ).

\section{Water quality}

Water quality in the reservoir was generally high (Table 2). Impounded water was soft and marginally alkaline, with low total dissolved solids content, and notably low nutrient ( $\mathrm{P}$ and $\mathrm{N}$ ) levels. Average ionic composition was characteristic of river water globally (Wetzel, 1983), with respective cation and anion rankings of $\mathrm{Ca}^{2+}$ $>\mathrm{Mg}^{2+}>\mathrm{Na}^{+}>\mathrm{K}^{+}$, and $\mathrm{CO}_{3}{ }^{2-}>\mathrm{Cl}^{-}>\mathrm{SO}_{4}{ }^{2-}$. 

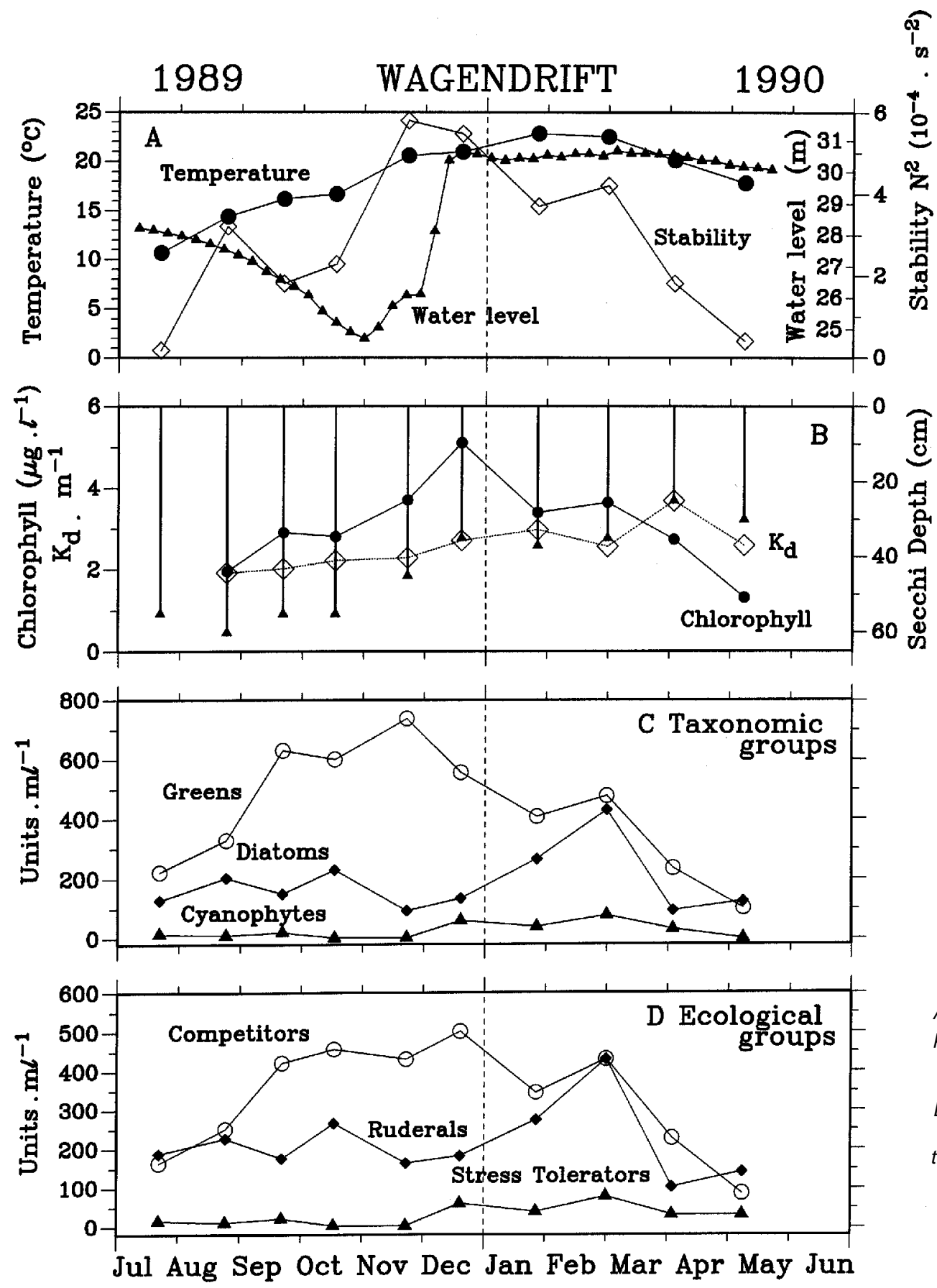

Figure 3

Seasonal changes in A) Water temperature (-•-), physical stability measured as $N^{2}(-\diamond-)$ and water level in $m$ above datum (- - -); B) Surface chlorophyll content (-•-) and water transparency as $\mathrm{K}_{d P A R}(-\diamond-)$ and Secchi depth (- $\mathbf{-}-)$; $C, D$ : Periodicity of principal taxonomic $(C)$ and ecological (D) categories of phytoplankton.

\section{Turbidity}

Turbidity in Wagendrift Dam was moderate during the study (Fig. 3B). SD transparency values ranged from 25 to $60 \mathrm{~cm}$ (average $=$ $43 \mathrm{~cm}$ ), and $K_{\mathrm{dPAR}}$ values averaged 2.55 (range $=1.9$ to $3.7 \cdot \mathrm{m}^{-1}$ ). Unlike neighbouring reservoirs in the Thukela Basin (notably Spioenkop and Chelmsford Dams (Hart, 1999)), turbidity in Wagendrift Dam was not consistently or obviously mineral in character, although the reduction in water transparency from November (Fig. 3B) accompanied rising water levels (Fig. 3A), and was attributable to suspended sediment inputs associated with river inflows following summer rains.

\section{Phytoplankton}

Phytoplankton abundance, measured as the integral signature of chlorophyll concentration, approximately doubled from winter lows of below $2.5 \mu \mathrm{g} \cdot \ell^{-1}$ to a maximum of $5 \mu \mathrm{g} \cdot \ell^{-1}$ in mid-summer (December), before declining to values below those recorded in the preceding winter (Fig. 3).

Approximately 50 taxa, roughly 20 of which were numerically important, were distinguished in the phytoplankton (see Table 3). Green algae were numerically dominant virtually throughout the year, followed in general rank order by diatoms and cyanophytes. Contrasting seasonal periodicity was exemplified by these three taxonomic groups, mirrored by the broadly corresponding $\mathrm{C}, \mathrm{R}$ and $\mathrm{S}$ ecological categories of algae (Fig. 3). Competitive C-type 
greens increased sharply in spring, and peaked in early summer. Disturbance-tolerant diatoms and desmids were most abundant in late summer, reaching a peak in early March, broadly concordant with hydraulic mixing accompanying peak river inflows, and annual destratification. Stress-tolerant cyanophytes, while never numerically abundant, were seasonally most prominent during stratified conditions from mid-summer through early autumn.

\section{Zooplankton}

The zooplankton taxa encountered during the study (Table 4) comprised one calanoid copepod (Tropodiaptomus spectabilis), three cladocerans (Daphnia pulex, D. laevis and Diaphanosoma excisum), a dipteran insect (Chaoborus sp.), and an array of unidentified cyclopoid copepods and rotifers. Of these, the collective entities of all cyclopoids and all rotifers, along with $D$. pulex, were numerically most abundant during the study period (Fig. 4). In contrast to the annual presence of D. pulex, Diaphanosoma excisum and $D$. laevis exhibited clear seasonal periodicity. The small sidiid cladoceran $D$. excisum was absent before mid-December, but thereafter increased rapidly to a peak in late January, and remained numerically important for the rest of the annual cycle, although it was clearly beginning to decline after April. D. laevis appeared briefly in low numbers between mid and late summer. T. spectabilis was present almost continuously, but increased to a January peak coincident both with the increase of $D$. excisum, and a significant decline in rotifer abundance.

Presence of breeding individuals of the specific taxa listed above (Figs. 4B, 4D, 4E and 4F), as well as the collective cyclopoid copepod assemblage (Fig. 4C) indicated that reproduction was virtually continuous during their seasonal presence. However, considerable changes in fecundity were evident during the respective breeding periods of all individual taxa (Fig. 5). The roughly 9-fold range in clutch-size in $D$. pulex was independent $\left(r^{2}=0.183\right.$, $p=0.251$ ) of significant changes (roughly 1.6 -fold) in parent body size. No comparably large changes in body size were evident in $T$. spectabilis, D. excisum or D. laevis, which showed respectively mean paired body length $(\mathrm{mm})$ and clutch-size (eggs.individual ${ }^{-1}$ ) ranges of 1.12 and 2.56, 1.07 and 4.57, and 1.13 and 2.0. Fecundity was unrelated to body size in the former two taxa $\left(r^{2}=0.304\right.$ and 0.331 , and $p=0.199$ and 0.251 , respectively), and statistically indeterminate in $D$. laevis (for which only two values existed). Clutch sizes of all taxa present in December - T. spectabilis (Fig. 5B), D. pulex and D. excisum (Fig. 5C) - were conspicuously higher than at any other time during the study. Food quantity as reflected in chlorophyll content was at a corresponding annual peak (Fig. 5A). Conversely, low clutch sizes in $T$. spectabilis and $D$. pulex at the outset of the study coincided with lower chlorophyll levels, conceivably depressed by the grazing pressure of the prevailing high zooplankton standing stocks (Fig. 5D). Overall, changes in clutch-size appear related to nutritional influences - changes in food quantity, and probably also food quality.

As a relatively large predator, Chaoborus was understandably rather sparse. In view of this low density, it is unclear whether the apparent bimodal pattern of abundance (Fig. $4 \mathrm{H}$ ) is a sampling artefact, or a real seasonal feature.

\section{Other fauna}

No benthic or fish sampling was attempted in this study. However, the $\pm 3 \mathrm{~m}$ drop in water during the earlier part of this study (Fig. 3A) exposed considerable marginal areas of the reservoir, stranding large numbers of the bivalve mollusc (Unio caffer). High densities (subjectively estimated at around 10 to 20 mussels $\cdot \mathrm{m}^{-2}$ ), and the predominance of large individuals (shell length $>60 \mathrm{~mm}$ ) in this population suggest that this benthic filter feeder may be a major faunal component of this ecosystem.

TABLE 2

Major water quality variables and dissolved constituents determined on $>450$ sampling dates between February 1983 and June 1998. Values in $\mathrm{mg} \cdot \ell^{-1}$, except where otherwise indicated. Data kindly supplied by DWAF (Geldenhuys et al., 1991).

\begin{tabular}{|l|c|c|}
\hline Determinant & $\begin{array}{c}\text { Median } \\
\text { value }\end{array}$ & 95\% CL ( $\mathbf{~})$ \\
\hline Electrical conductivity $\left(\mathrm{mS} \cdot \mathrm{m}^{-1}\right)$ & 7.3 & 0.1 \\
$\mathrm{pH}(\mathrm{pH}$ units) & 7.5 & 0.1 \\
Total dissolved solids & 55.0 & 1.0 \\
$\mathrm{Na}^{+}$ & 3.0 & $<0.1$ \\
$\mathrm{Mg}^{2+}$ & 3.0 & $<0.1$ \\
$\mathrm{Ca}^{2+}$ & 6.0 & $<0.1$ \\
$\mathrm{~K}^{+}$ & 0.7 & 0.1 \\
$\mathrm{Si}^{+}$ & 6.6 & 0.1 \\
$\mathrm{Total}^{+}\left(\mathrm{CaCO}_{3}\right)$ alkalinity & 27.0 & 1.0 \\
$\mathrm{SO}_{4}^{2-}$ & 5.0 & $<0.1$ \\
$\mathrm{Cl}^{-}$ & 4.0 & $<0.1$ \\
$\mathrm{~F}^{-}$ & 0.11 & 0.01 \\
$\mathrm{PO}_{4}-\mathrm{P}$ & 0.015 & 0.001 \\
$\mathrm{NH}_{4}^{-} \mathrm{N}$ & 0.04 & $<0.1$ \\
$\mathrm{NO}_{3}+\mathrm{NO}_{2}-\mathrm{N}$ & 0.17 & 0.1 \\
& & \\
\hline
\end{tabular}

\begin{tabular}{|l|l|l|l|}
\hline \multicolumn{4}{|l|}{ TABLE 3 } \\
Principal genera (and number of separate species) recorded as \\
prominent representatives of the phytoplankton in Wagendrift Dam
\end{tabular}




\begin{tabular}{|c|c|c|c|}
\hline \multicolumn{4}{|c|}{$\begin{array}{c}\text { TABLE } 4 \\
\text { Zooplankton taxa from Wagendrift Dam, and dry weight coefficients } \\
\text { (published own and other data) used to estimate zooplankton biomass }\end{array}$} \\
\hline & Taxon & Stage/category & $\begin{array}{c}\text { Biomass } \\
(\mu \mathrm{g})\end{array}$ \\
\hline Rotifera & All species & Individuals & 0.075 \\
\hline \multirow[t]{5}{*}{ Crustacea } & Daphnia pulex Leydig & $\begin{array}{l}\text { Non-ovigerous } \\
\text { Ovigerous }\end{array}$ & $\begin{array}{l}11.3 \\
18.8\end{array}$ \\
\hline & Daphnia laevis Birge & $\begin{array}{l}\text { Non-ovigerous } \\
\text { Ovigerous }\end{array}$ & $\begin{array}{c}7.5 \\
12.5\end{array}$ \\
\hline & $\begin{array}{l}\text { Diaphanosoma excisum } \\
\text { Sars }\end{array}$ & $\begin{array}{l}\text { Non-ovigerous } \\
\text { Ovigerous }\end{array}$ & $\begin{array}{l}1.6 \\
2.6\end{array}$ \\
\hline & Cyclopoid copepods (species combined) & $\begin{array}{l}\text { Nauplii } \\
\text { Copepodite stages I to VI } \\
\text { Ovigerous females }\end{array}$ & $\begin{array}{l}0.2 \\
1.0 \\
1.5\end{array}$ \\
\hline & Tropodiaptomus spectabilis (Kiefer) & $\begin{array}{l}\text { Nauplii } \\
\text { Copepodite stages I to III } \\
\text { Copepodite stages IV to V } \\
\text { Adult males } \\
\text { Adult females } \\
\text { Ovigerous females }\end{array}$ & $\begin{array}{c}1.5 \\
3.7 \\
7.5 \\
12.5 \\
15.0 \\
20.0\end{array}$ \\
\hline $\begin{array}{l}\text { Insecta } \\
\text { (Diptera) }\end{array}$ & Chaoborus? flavicans & All larval instars & 75.0 \\
\hline
\end{tabular}

\begin{tabular}{|c|c|c|}
\hline \multicolumn{3}{|c|}{$\begin{array}{l}\text { TABLE } 5 \\
\text { Comparative mean limnological attributes of } \\
\text { Wagendrift and Spioenkop Dams (Hart, 1999 and } \\
\text { unpublished) during this study (1989/1990), along } \\
\text { with } 1983 \text { to } 1998 \text { mean nutrient concentrations } \\
\text { (DWAF records). The N:P ratio is based on } \\
\text { listed determinants. }\end{array}$} \\
\hline Variable & $\begin{array}{l}\text { Wagendrift } \\
\text { Dam }\end{array}$ & $\begin{array}{c}\text { Spioenkop } \\
\text { Dam }\end{array}$ \\
\hline $\mathrm{N}^{2}\left(10^{-4} \cdot \mathrm{s}^{-2}\right)$ & 2.89 & 2.51 \\
\hline$K_{\mathrm{dPAR}}\left(\mathrm{m}^{-1}\right)$ & 2.55 & 3.84 \\
\hline $\mathrm{SD}(\mathrm{cm})$ & 43.2 & 26.6 \\
\hline $\mathrm{PO}_{4}-\mathrm{P}\left(\mathrm{mg} \cdot \ell^{-1}\right)$ & 0.018 & 0.03 \\
\hline $\mathrm{NO}_{3}+\mathrm{NO}_{2}+\mathrm{NH}_{4}-\mathrm{N}\left(\mathrm{mg} \cdot \ell^{-1}\right)$ & 0.22 & 0.37 \\
\hline $\mathrm{N}: \mathrm{P}$ & 12.2 & 12.3 \\
\hline Chlorophyll $\left(\mu \mathrm{g} \cdot \ell^{-1}\right)$ & 3.07 & 2.68 \\
\hline \multicolumn{3}{|l|}{ Zooplankton biomass $\left(\mathrm{g} \cdot \mathrm{m}^{-2} \mathrm{DM}\right)$} \\
\hline Including Chaoborus & 0.64 & 0.24 \\
\hline Excluding Chaoborus & 0.58 & 0.21 \\
\hline
\end{tabular}

\section{Discussion}

\section{Physico-chemical limnology}

Like other deeper reservoirs in KwaZulu-Natal such as those on the Mgeni River (Hart, 1992a, 1996), and Spioenkop Dam on the
Thukela River (Hart, 1999), Wagendrift Dam shows a typical pattern of holomictic monomixis. Its general thermal regime was comparable to that reported for Spioenkop Dam for the same period, but with a slightly lower thermal minimum $\left(\sim 11^{\circ} \mathrm{C}\right.$ vs. $\sim 12^{\circ} \mathrm{C}$ in Spioenkop) plausibly attributable to Wagendrift's $\sim 110 \mathrm{~m}$ higher elevation. The intensity of stratification of both reservoirs was closely comparable (Table 5), with respective annual mean and

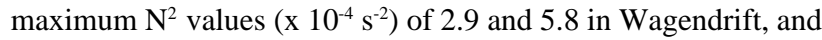
2.5 and 5.2 in Spioenkop, despite the greater surface heating potential associated with Spioenkop's high mineral turbidity. Both reservoirs contrast with Sterkfontein Dam, a clear-water system which shows a much lower annual thermal range $\left( \pm 8\right.$ to $\left.\pm 21^{\circ} \mathrm{C}\right)$, notably lower winter minima (Dörgeloh et al.,1993), and weaker stratification (maximum $\mathrm{N}^{2}$ of $3.6 \times 10^{-4} \mathrm{~s}^{-2}$ interpolated from Fig. 2 in Dörgeloh et al. (1993). These thermal features are collectively attributable to the much higher elevation $(1620 \mathrm{~m})$, greater maximum depth $(82 \mathrm{~m})$, and far greater surface area (6940 ha) available for evaporative and nocturnal convective cooling of this distantly neighbouring system. The rapid cooling evident after overturn in April in all three reservoirs is attributable to the relative severity of the Drakensberg climate which they broadly share (Schulze, 1997).

Comparison with sequential reservoirs along the Mgeni River (Midmar, Albert Falls, Nagle, and Inanda Dams) is less founded, in view of their lower elevation and more mesic location. These water bodies show progressively warmer thermal regimes, and accordingly stronger stratification and physical stability down this reservoir cascade. Respective summer mean $\mathrm{N}^{2}$ values in the upper two impoundments are around 6.6 and $8.7 \times 10^{-4} \mathrm{~s}^{-2}$, with considerably higher seasonal maxima (Hart, 1992a). 
Little can be said regarding other abiotic features of Wagendrift Dam, apart from noting the relative clarity and low nutrient status of its waters - especially notable in view of the extent of human settlement in its proximate catchment (Fig. 1). As regards nutrient status, the marginal enrichment of $\mathrm{P}$ relative to $\mathrm{N}$ (Redfield, 1958) is common to both impoundments (Table 5), and is probably a natural consequence of shared geology rather than any anthropogenic influence. The lower nutrient levels in Wagendrift Dam are probably attributable to comparable reasons suggested for the contrast in turbidity. But unlike other impoundments such as Spioenkop (Hart, 1999) or Vanderkloof Dams (Allanson and Jackson, 1983), where turbidity is manifested primarily by suspended sediments, and the water is visibly 'muddy', suspended sediments were generally inconspicuous in Wagendrift.

The character of the turbidity, along with the low nutrient levels recorded jointly suggest that despite the potential for adverse anthropogenic influences, the Boesmans River catchment was in reasonable condition at the time of the study. This topic is explored further and discussed in Limnological inferences on catchment conditions below.

\section{Biological limnology}

In common with the physico-chemical findings discussed above, no major undesirable or negative limnological features of Wagendrift Dam are reflected by the present findings in respect of its planktonic biota. Dominance of the phytoplankton by green algae and diatoms, and the notable sparsity of cyanophytes in particular, jointly reflect desirable water quality characteristics which are indicative of a healthy lentic ecosystem. This evaluation is concordant with the relatively low biomass of algae that is able to develop.

Although preceded by a progressive increase in chlorophyll level, attainment of the annual peak in chlorophyll in mid-summer (Fig. 3B) coincided with rising water levels associated with river inflows, and concurrent reduction in water transparency. This suggests that phytoplankton may have increased in response to fresh nutrient inputs.

Limitation of algal growth is plausibly attributable not only to relatively low nutrient status and moderate light limitation, but potentially also reflects the grazing control effected by zooplankton, and perhaps also benthic bivalve molluscs. Zooplankton community grazing rates predicted from present estimates of zooplankton biomass for Wagendrift Dam using Lampert's (1988) regression equation reflect instantaneous grazer-induced algal mortality rates of between 0.11 and $0.24 \mathrm{~d}^{-1}\left(\right.$ mean $\left.=0.18 \mathrm{~d}^{-1}\right)$. Such rates, the average of which is roughly equivalent to a daily filtration rate of $18 \%$ of the environment (Sterner, 1989), indicate a significant impact of grazers in the 'control' of planktonic algae.

Additional filtration effects are likely to be exerted by benthic fauna such as the large-bodied, suspension-feeding bivalve Unio

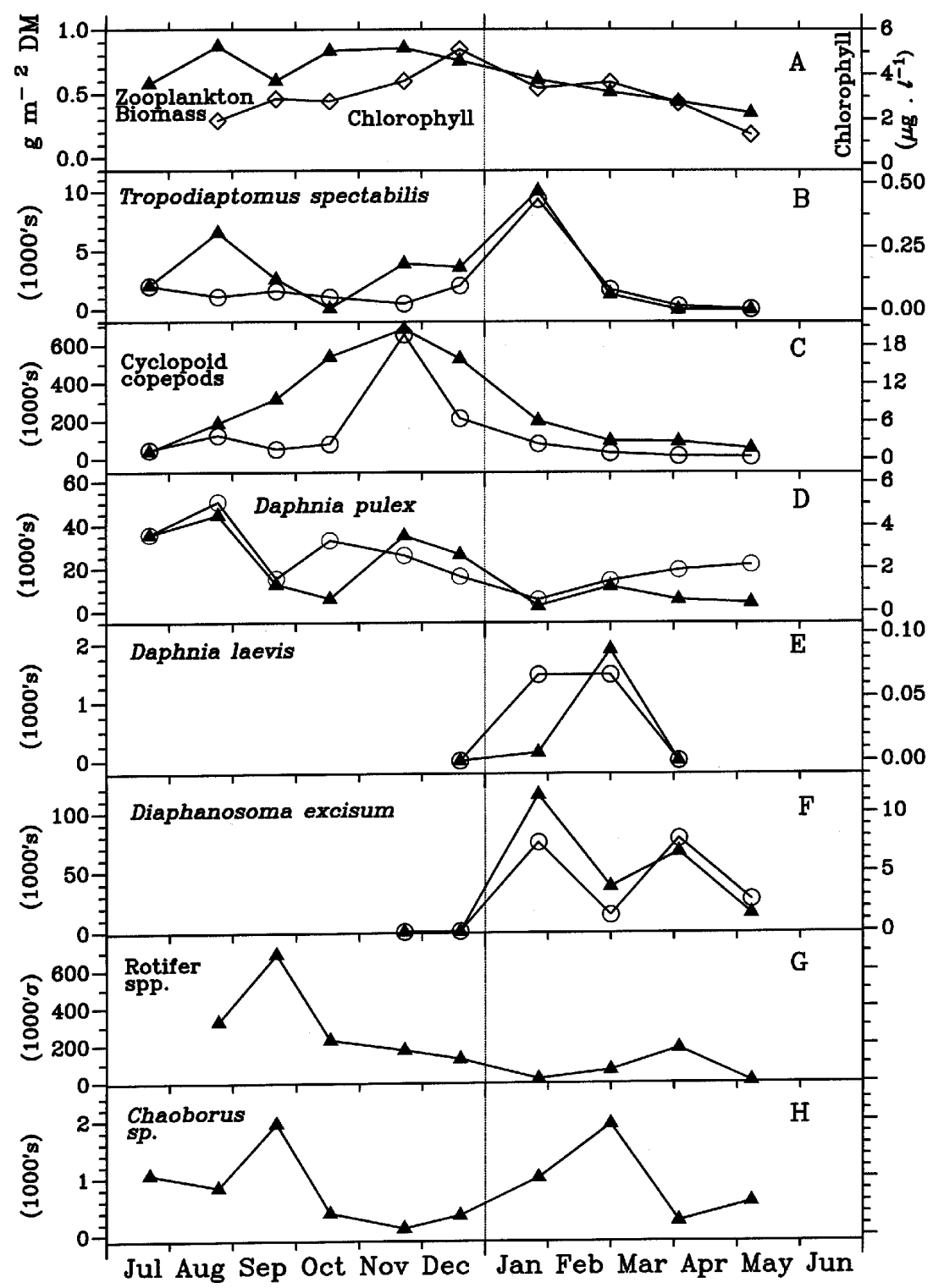

Figure 4

Total zooplankton biomass ( $-\mathbf{\Delta}-$ in A), and seasonal periodicity and chlorophyll content (- $\diamond-$ in A) in Wagendrift Dam during 1989/90. Panels B to $F$ show total population densities (- - , left-hand ordinates) and densities of breeding individuals (- - -, right-hand ordinates).

caffer, observed in considerable numbers at least in the shallower marginal regions of Wagendrift Dam. Such bivalves are individually capable of filtering prodigious volumes of water - around 1 to 3 $\ell \cdot h^{-1}$ (Kenmuir, 1980). As no estimate of their abundance is available, their filtration effect in Wagendrift Dam cannot be judged. The mean mussel density of $29 \mathrm{~m}^{-2}$ reported for the extensive Sanyati East area of Lake Kariba (Kenmuir, 1980) indicates the potential magnitude of their impact - the filtration of (conservatively) $700 \ell \cdot \mathrm{m}^{-2} \cdot \mathrm{d}^{-1}$. For a water column of $4 \mathrm{~m}$ depth, this represents a grazing rate of $0.17 \mathrm{~d}^{-1}$, roughly equivalent to the average zooplankton grazing rate in Wagendrift Dam.

The obligatory temporary parasitism of unionid and mutelid bivalves on fish for completion of their life cycle (Appleton, 1996), indicates further the persistence of appropriate fish host species in the reservoir or its influent river. However, as dependency on 


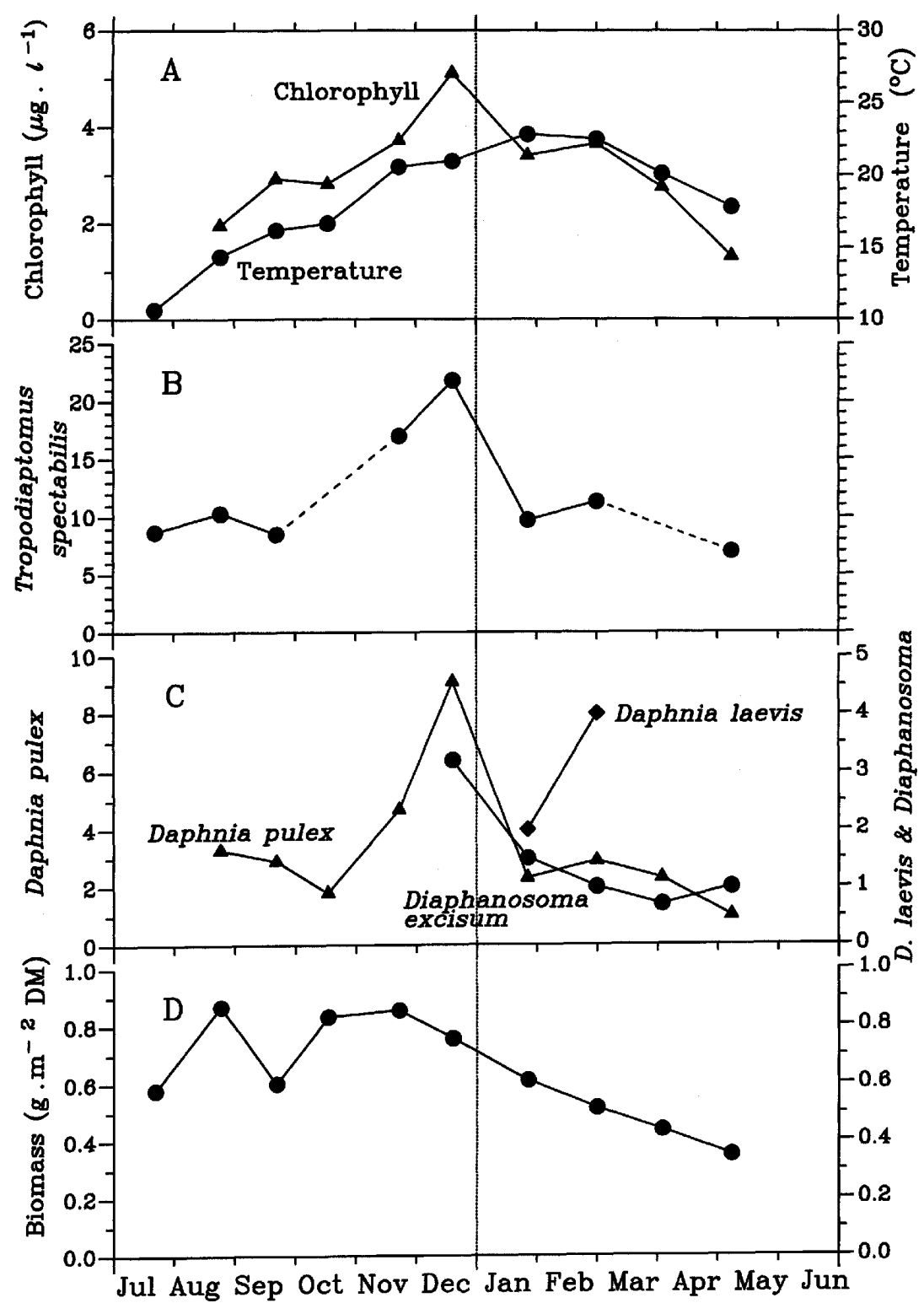

Figure 5

Changes in mean clutch sizes of specific copepods $(B)$ and cladocerans $(C)$ in relation to (A) annual changes in food supply (- - -) and temperature (- - ), and the abundance of potential food competitors (D)

specific fish hosts is not absolute (Kenmuir, 1980), the existence of $U$. caffer in Wagendrift Dam cannot be linked to the existence of one particular species of fish. But their hosts are more plausibly indigenous than introduced fish species.

Seasonality of phytoplankton and zooplankton was only moderate during the study period. Chlorophyll, as an index of phytoplankton abundance, showed an annual variation (maximum/ minimum ratio) of 3.9 , while zooplankton varied 2.5 -fold in terms of estimated biomass (or 4.1-fold in terms of empirical measurements of settled volume). This latter measure includes phytoplankton components of the net catch and accordingly over-estimates zooplankton to a variable extent depending on concurrent algal abundance. Corresponding values for Spioenkop Dam were 3.5 for chlorophyll and 22.8 for zooplankton biomass, reflecting surprisingly similar phytoplankton variability, but much greater seasonality of zooplankton in that turbid reservoir.
Certain zooplankton taxa in Wagendrift Dam exhibited profound seasonal changes in mean clutch size (Fig. 5). These changes were unrelated to, or unaccompanied by parallel changes in parent body size, suggesting a strong nutritional influence on fecundity of the zooplankton taxa involved. Surprisingly, however, this influence did not translate into corresponding changes in total zooplankton abundance, which showed limited seasonal variation in Wagendrift. No explanation can be offered for the failure of this 'cascade' effect.

The strong disparity in total zooplankton biomass between Wagendrift and Spioenkop Dams, despite their reasonably comparable chlorophyll levels (Table 5) emphasises the now well-known negative impact of suspended sediment on zooplankton (Arruda et al., 1983; Hart, 1988; Kirk, 1991). However, experimental evidence showing that the primary negative effect of suspended sediments on cladoceran zooplankton is to restrict food availability per se (Hart, 1992b) through direct light limitation of photosynthesis rather than on these grazers' ability to exploit the available food supply, is difficult to reconcile with the scale of the apparent negative effect of sediment turbidity, especially in Spioenkop Dam. The mean zooplankton standing stock in Wagendrift was roughly 2.6-fold greater than in Spioenkop, against a mere 1.1-fold higher mean chlorophyll level. The dilemma of explaining these contrasting field data merely highlights the confounding effects of a wide and complex array of natural influences and interactions - the reality of holistic rather than reductionist approaches to limno-ecology.

\section{Limnological inferences on catchment conditions}

The relatively low suspended sediment turbidity, and somewhat lower nutrient status of Wagendrift in comparison with Spioenkop Dam (Table 5) suggests that the Boesmans River catchment was in better condition than that of the Thukela River during the study period, although circumstances may well have changed in the intervening decade. The turbidity difference is especially notable. It exists despite the generally similar physiography (geology, soil type), climate, vegetation and, hence, erodibility in the two catchments (Midgley et al., 1994; Schulze, 1997). It is even more surprisingly in view of the much greater human settlement in proximity to Wagendrift Dam (Fig. 1). Spioenkop Dam remained highly turbid despite the effective existence of pre-impoundments (Woodstock Dam and Driel Barrage) which precede it in the reservoir cascade which it terminates. Limnological inferences regarding poor land use in Spioenkop Dam's drainage basin have been discussed elsewhere (Hart, 1999). The question arising from the present findings is perhaps rather why Wagendrift Dam appears to be less severely impacted than Spioenkop Dam, despite the greater human population density in its local catchment. 
Two apparent features arise in this regard. Firstly, the spatial distribution of the human inhabitants, and secondly, their socioeconomic activities. Human settlement in the Wagendrift Dam basin is concentrated in satellite townships located on more gentlysloping lower ground in close proximity to Estcourt, where many of the satellite dwellers are employed. The livelihood of such wage-earners does not depend exclusively on subsistence agriculture, although this is used widely to augment survival. This contrasts with the predominantly rural and subsistence habitation of the Thukela catchment, the upper reaches of which are less confined to enforced conservancy areas. Subsistence agriculturalists and pastoralists encroach further into higher, steeper reaches, generating more erosion, especially through overgrazing, and clearing and/or harvesting of soil-binding vegetation, than in the Boesmans River basin.

The present comparison perhaps adds the following counterintuitive perspective to a regional understanding of water resource management. Namely, that gainfully employed people living in intensive settlements may pose a lesser threat to catchments than a more dispersed population pursuing a subsistence livelihood. This interpretation contradicts directly the prevailing paradigm that human concentrations adversely affect water resources, as already well-documented in Southern Africa (Selkirk and Hart, 1984), and emphatically highlights the importance of site-specific evaluation. As explicitly encapsulated by Hynes (1975), the stream is its valley. We all recognise and acknowledge that each valley is different, but too few impoundments have been investigated in the region to begin formative generalisations. The acquisition of system-specific knowledge and understanding, especially in developing countries, has been and remains compromised for recognisable economic reasons that are well-known. However, practical implementation of integrated catchment management, as the only conceivable means to secure a future for the world's most-limiting natural resource, depends totally on developing this understanding, which encompasses crucial socio-economic and political dimensions. The establishment of Catchment Management Agencies, as envisaged in consequence of the National Water Act (Act 36 of 1998), should be appropriately localised.

\section{Acknowledgements}

Funds for this study were awarded by the National Research Foundation (formerly FRD) and the University of Natal Research Committee (URC). Special thanks are due to Rei Hart, for her proficient microscopic analyses of plankton samples. Officer Graham Addison of the KwaZulu-Natal Nature Conservation Service (KZNNCS, formerly Natal Parks Board) provided logistic support and co-operation at Wagendrift Dam. Dr Nancy Rayner assisted with zooplankton identifications. Water chemistry and hydrological data incorporated here were kindly provided by DWAF, Pretoria.

\section{References}

ALLANSON BR, HART RC, O'KEEFFE JH and ROBARTS RD (1990) Inland Waters of Southern Africa. An Ecological Perspective. Kluwer Academic Press, Dordrecht. 458 pp.

ALLANSON BR and JACKSON PBN (eds.) (1983) The Limnology and Fisheries Potential of Lake le Roux. South African National Scientific Programmes Report No 77. CSIR, Pretoria. 182 pp.

APPLETON CC (1996) Freshwater Molluscs of Southern Africa. Univ. of Natal Press, Pietermaritzburg. 64 pp.

ARRUDA JA, MARZOLF GR and FAULK RT (1983) The role of suspended sediments in the nutrition of zooplankton in turbid reservoirs. Ecol. 64 1225-1235.
BREEN CM (1983) Limnology of Lake Midmar. South African National Scientific Programmes Report No 78. CSIR, Pretoria. $140 \mathrm{pp}$.

DÖRGELOH WG, SEAMAN MT and GAIGHER IG (1993) The physical and chemical limnology of Sterkfontein Dam, Eastern Free State, South Africa. Water SA 19 177-184.

DEPARTMENT OF WATER AFFAIRS (1986) Management of the Water Resources of the Republic of South Africa. Department of Water Affairs, Pretoria. (ca 494 pp.)

GELDENHUYS W, NELL U and VAN VEELEN M(1991) Surface Water Quality of South Africa; 1979 - 1988. Technical Report No 145. Department of Water Affairs and Forestry, Pretoria. $27+$ pp.

GRAHAM PM, DICKENS CWS and MBOWA S (1998) Modelling the Water Quality in Impoundments within the Umgeni Water Operational Area and the Consequences for Potable Water Treatment Costs. WRC Report No 615/1/98.

GRIME JP (1979) Plant Strategies and Vegetation Processes. Wiley Interscience, Chichester. $222 \mathrm{pp}$.

HART RC (1988) Zooplankton feeding rates in relation to suspended sediment content: Potential influences on community structure in a turbid reservoir. Freshwater Biol. 19 123-139.

HART RC (1992a) Aspects of comparative plankton ecology in cascading Mgeni River reservoirs (Midmar, Albert Falls, and Nagle): An overview. S. Afr. J. Aquat. Sci. 18 20-41.

HART RC (1992b) Experimental studies on food and suspended sediment effects on growth and reproduction of six planktonic cladocerans. $J$. Plankton Res. 14 1425-1448.

HART RC (1996) Comparative ecology of plankton in cascading warmwater reservoirs: Aspects of relevance to tropical limnology. In: Schiemer F and Boland KT (eds). Perspectives in Tropical Limnology. SPB Academic Publishing bv, Amsterdam. 113-130.

HART RC (1999) On the limnology of Spioenkop, a turbid reservoir on the upper Thukela River, with particular reference to its plankton community. Water SA 25 519-528.

HYNES HBN (1975) The stream and its valley. Verh. Int. Ver. Limnol. 19 $1-15$.

KENMUIR DHS (1980) Aspects of the Biology and Population Dynamics of Freshwater Mussels in Lake Kariba and Lake McIlwaine. Ph.D. Dissertation, Dept. of Zool. \& Entomol., Univ. of Natal, Pietermaritzburg. $381 \mathrm{pp}$.

KIENZLE SW, LORENTZ SA and SCHULZE RE (1997) Hydrology and Water Quality of the Mgeni Catchment. WRC Report No TT87/97.

KIRK KL (1991) Suspended clay reduces Daphnia feeding rate: Behavioural mechanisms. Freshwater Biol. 25 357-365.

LAMPERT W (1988) The relationship between zooplankton biomass and grazing: A review. Limnologica (Berlin) 19 11-20.

LUND JWG, KIPLINGC and LeCRENED (1958) The inverted microscope method of estimating algal numbers and the statistical basis of estimations by counting. Hydrobiol. 11 143-170.

MIDGLEY DC, PITMAN W V and MIDDLETON BJ (1994) Surface Water Resources of South Africa 1990: VI. WRC Report No 298/6.1/ 94.

NATIONAL INSTITUTE FOR WATER RESEARCH (1985) The Limnology of Hartbeespoort Dam. South African National Scientific Programmes Report No 110. CSIR, Pretoria. 269 pp.

NOBLE RG and HEMENS J (1978) Inland Water Ecosystems in South Africa - A Review of Research Needs. South African National Scientific Programmes Report No 34. CSIR, Pretoria. 150 pp.

O'KEEFFE JH, VAN GINKEL CE, HUGHES DA, HILL TR and ASHTON PJ (1996) A Situation Analysis of Water Quality in the Catchment of the Buffalo River, Eastern Cape, with Special Emphasis on the Impacts of Low Cost, High-Density Urban Development on Water Quality. WRC Report No 405/1/96.

PATERSON JC, HAMBLIN PF and IMBERGER J (1984) Classification and dynamic simulation of the vertical density structure of lakes. Limnol. Oceanogr. 29 845-861.

PIETERSE AJH and KEULDER PC (eds.) (1982) The Limnology of a Shallow, Turbid Impoundment, Wuras Dam. A Study of the Role of Suspensoids. Report of the Working Group for Limnology, Univ. of the Free State, Bloemfontein. 89 pp.

REDFIELD AC (1958) The biological control of chemical factors in the environment. Am. Sci. 46 205-221. 
REYNOLDS CS (1984) Phytoplankton periodicity: The interaction of form, function and environmental variability. Freshwater Biol. 14 111-142.

REYNOLDS CS (1996) The plant life of the pelagic. Verh. Int. Ver. Limnol. 26 97-113.

REYNOLDS CS (2000) Defining sustainability in aquatic ecosystems: A thermodynamic approach. Verh. Int. Ver. Limnol. 27 107-117.

SCHULZE RE (1997) South African Atlas of Agrohydrology and -Climatology. WRC Report No TT 82/96.

SELKIRK WT and HART RC (1984) The Buffalo River Catchment. Eutrophication and Mineralization of the Buffalo River Reservoirs. An Overview for 1983. Institute for Freshwater Studies Special Report No 84/1, Rhodes Univ., Grahamstown. 56 pp.

STERNER RW (1989) The role of grazers in phytoplankton succession. In: Sommer U (ed.) Plankton Ecology. Succession in Plankton Communities. Springer-Verlag, Berlin. 107-170.
TOW M (1981) Physico-Chemical Limnology of Bridle Drift, Laing and Nahoon Dams. Water Research Commission and National Institute for Water Research collaborative report. Pretoria. 65 pp.

UYS M (1996) A Structural Analysis of the Water Allocation Mechanism of the Water Act 54 of 1956 in the Light of the Requirements of Competing Water User Sectors. WRC Report No 406/1/96.

VAN GINKEL CE (1987) 'n Ondersoek Na die Rol van Soöplankton in Roodeplaatdam. Technical Report No TR 127. Department of Water Affairs, Pretoria. 120 pp.

WALMSLEY RD and BUTTY M (1980) The Limnology of Some Selected South African Impoundments. Water Research Commission and National Institute for Water Research collaborative report. Pretoria. 229 pp.

WETZEL RG (1983) Limnology (2nd edn.). WB Saunders, Philadelphia. $767+81+10 \mathrm{pp}$ 